\title{
Two bacterial infection models in tree shrew for evaluating the efficacy of antimicrobial agents
}

\author{
LI Sheng-An ${ }^{1,2}$, LEE Wen-Hui ${ }^{1, *}$, ZHANG Yun ${ }^{1, *}$ \\ (1. Key Laboratory of Animal Models and Human Disease Mechanisms of the Chinese Academy of Sciences \& Yunnan Province, Kunming Institute of Zoology, \\ the Chinese Academy of Sciences, Kunming Yunnan 650223, China; 2. Graduate School of the Chinese Academy of Science, Beijing 100049, China)
}

\begin{abstract}
Animal models are essential for the development of new anti-infectious drugs. Although some bacterial infection models have been established in rodents, small primate models are rare. Here, we report on two bacterial infection models established in tree shrew (Tupaia belangeri chinensis). A burnt skin infection model was induced by dropping $5 \times 10^{6} \mathrm{CFU}$ of Staphylococcus aureus on the surface of a wound after a third degree burn. This dose of $S$. aureus caused persistent infection for 7 days and obvious inflammatory response was observed 4 days after inoculation. A Dacron graft infection model, $2 \times 10^{6} \mathrm{CFU}$ of Pseudomonas aeruginosa also caused persistent infection for 6 days, with large amounts of pus observed 3 days after inoculation. These models were used to evaluate the efficacy of levofloxacin (LEV) and cefoperazone (CPZ), which reduced the viable bacteria in skin to $4 \log _{10}$ and $5 \log _{10} \mathrm{CFU} / 100 \mathrm{mg}$ tissue, respectively. The number of bacteria in graft was significantly reduced by $4 \log _{10} \mathrm{CFU} / \mathrm{mL}$ treatment compared to the untreated group $(P<0.05)$. These results suggest that two bacterial infection models were successfully established in tree shrew using $P$. aeruginosa and $S$. aureus. In addition, tree shrew was susceptible to $P$. aeruginosa and $S$. aureus, thus making it an ideal bacterial infection animal model for the evaluation of new antimicrobials.
\end{abstract}

Key words: Tree shrew; Novel antimicrobials; Graft infection; Staphylococcus aureus; Pseudomonas aeruginosa

\section{树鼠细菌感染模型的建立及抗菌药物的治疗效果评价}

\author{
李盛安 ${ }^{1,2}$, 李文辉 ${ }^{1, *}$, 张 云 ${ }^{1, *}$ \\ (1. 中国科学院和云南省动物模型与人类疾病机理重点实验室, 中国科学院昆明动物研究所, 云南 昆明 650223 ;
}

2. 中国科学院研究生院, 北京 100049)

摘要: 在抗微生物感染药物开发过程中, 动物模型是必不可少的。虽然目前已经用啮齿类动物建立了一些细 菌感染动物模型, 但在小型灵长类动物中还很少见。这里首次报道两个树鼣细菌感染动物模型。第一种是在三度 烫伤后的皮肤表面接种 $5 \times 10^{6} \mathrm{CFU}$ 的金黄色葡萄球菌构建的皮肤烫伤感染模型。这个数量的金黄色葡萄球菌可以 造成 $7 \mathrm{~d}$ 持续性感染, 并且在第 4 天可以看到明显的炎症反应。第二种是用绿脓杆菌构建的涤纶补片感染模型，接 种 $2 \times 10^{6} \mathrm{CFU}$ 的绿脓杆菌同样可以引起持续 $6 \mathrm{~d}$ 感染, 并在第三天在伤口处观察到大量的脓液。进一步用这两种 模型评价头孢哌酮钠和左氧氟沙星的治疗效果。左氧氟沙星和头孢哌酮钠在皮肤菏伤感染模型中能分别将 100 $\mathrm{mg}$ 皮肤组织中的细菌降低到 $4 \log _{10}$ 和 $5 \log _{10} \mathrm{CFU}$, 并且在涤纶补片植入感染模型中这两种抗生素都能显著地将感 染的细菌降低了 $4 \log _{10} \mathrm{CFU}(P<0.05)$ 。结果表明用金黄色葡萄球菌和绿脓杆菌成功构建了两个细菌感染的树鼠模 型。此外, 树鼠对金黄色葡萄球菌和绿脓杆菌很敏感, 适合用于构建细菌感染动物模型和评价新的抗细菌感染药物 的效果。

关键词：树獡; 新型抗菌药物; 移植物感染; 金黄色葡萄球菌; 绿脓杆菌

中图分类号：Q939.9; Q959.848 文献标志码：A 文章编号：0254-5853-(2012)01-0001-06

Received date: 2011-10-17; Accepted date: 2012-01-10

Foundation items: This study was financially supported by the Project from the Chinese Academy of Sciences (KSCX2-EW-R-11), the Key Laboratory of Animal Models and Human Disease Mechanisms of the Chinese Academy of Sciences \& Yunnan Province (KSCX2-EW-J-23), and Science and Technology Department of Yunnan Province (2011C1139)

${ }^{*}$ Corresponding author (通信作者), Tex/Fax: 0871-5195684, E-mail: zhangy@mail.kiz.ac.cn; leewh@mail.kiz.ac.cn

收稿日期：2011-10-17；接受日期：2012-01-10 
Bacterial infection is a serious disease affecting the health of humans. Traditional antibiotics have been widely applied in clinics since the first antibiotic, penicillin, was discovered, which has resulted in the emergence of many antibiotic-resistant strains all over the world (Fischbach \& Walsh, 2009; Givskov \& Hentzer, 2003; McPhee \& Hancock, 2005; Oyston et al, 2009; Zasloff, 2002). More powerful antimicrobials are urgently needed to conquer infections induced by drugresistant bacteria. Testing the therapeutic potential of new antimicrobial drugs in animal models is a very important stage of that process (Craig, 1993). To date, bacterial infection models have been established in mice, rats, and rabbits, but no models have been developed for small primate species (McCormick et al, 2008; Retsema et al, 1993; Russo et al, 2008). The mechanisms of infectious disease in non-primates are not similar with humans and although some antimicrobials have been found useful in non-primate animal models, they lost their activity during clinical trials(Druilhe et al, 2002). Murine species used as experimental animals have the advantages of economy and simple conduct, but they are ill suited for research on human infectious disease. The generation of a new, cost-effective, primate-like, smallanimal model would greatly facilitate research into bacterial infectious disease and the development of novel therapeutic approaches to bacterial infection (Niewiesk \& Prince, 2002).

Tree shrews are non-rodent, primate-like animals classified into the order Scandentia (Muller et al, 1999). This animal is a native of Yunnan, China, but related species are found all over South-east Asia. There is increasing interest in using them to establish animal models for medical and biological research (Yang et al, $2003)$ as they are susceptible to infection with a variety of human viruses in vivo, including hepatitis (Zhao et al, 2002).

To the best of our knowledge, the establishment of bacterial infection models in tree shrew is rare. In the current study, bacterial counts and histopathological examination were employed to investigate the susceptibility of tree shrew to pathogens, and two bacterial infection models were established using $P$. aeruginosa and $S$. aureus to evaluate the efficacy of antimicrobial agents.

\section{Materials and Methods}

\subsection{Bacterial strains and antibiotics}

Strains P. aeruginosa ATCC 27853 and S. aureus
ATCC 25923 were obtained from the First Affiliated Hospital of Kunming Medical College (China). Bacteria were cultured in nutrient broth, and incubated at $37{ }^{\circ} \mathrm{C}$ overnight. Bacteria were then washed three times with phosphate buffer solution (PBS) by repeated centrifugation for $10 \mathrm{~min}$ at $1000 \mathrm{r} / \mathrm{min}$, and resuspended in PBS. The CPZ and LEV were obtained from the General Pharmaceutical Factory of Harbin Pharmaceutical Group (Harbin, China). All other reagents were of analytic grade from commercial sources.

\subsection{In vitro susceptibility of antibiotics}

Serial dilution was used as previously described (Zhang et al, 2010). Briefly, minimal inhibitory concentration (MIC) was determined by incubating the bacteria $\left(5 \times 10^{5} \mathrm{CFU} / \mathrm{mL}\right)$ in Luria-Bertani (LB) broth $(\mathrm{pH} 7.0)$ with variable amounts of the sample tested for $16-18 \mathrm{~h}$ at $37{ }^{\circ} \mathrm{C}$. The sample concentrations were the same for each of the tested bacterial strains in three independent experiments and the MIC values were obtained without inter-experiment variations and expressed as $\mu \mathrm{g} / \mathrm{mL}$.

\subsection{Animals}

Adult tree shrews (Tupaia belangeri chinensis) weighing 120-150 g were used in this study. Animals were provided by the Animal Center of the Kunming Institute of Zoology. All animals were housed in individual cages under constant temperature $\left(22{ }^{\circ} \mathrm{C}\right)$ and humidity with a $12 \mathrm{~h}$ light/dark cycle and had ad libitum access to chow and water throughout the study. Tree shrews were euthanized by ether inhalation at the completion of the experiments. Animal care and handling were conducted in accordance with policies on the care and use of animals promulgated by the Ethics Committee of the Kunming Institute of Zoology, Chinese Academy of Sciences.

\subsection{Burned skin infection model}

A third degree burn skin infection model was developed in tree shrews by using $S$. aureus (Dale et al, 2004). Briefly, tree shrews were anesthetized with 90 $\mathrm{mg} / \mathrm{kg}$ ketamine $\mathrm{HCl}$ and $10 \mathrm{mg} / \mathrm{kg}$ xylazine. Hair was clipped from the back of anesthetized tree shrews and skin was denuded with $10 \% \mathrm{Na}_{2} \mathrm{~S}$ solution. Then, thermal injury was induced by placing a $90{ }^{\circ} \mathrm{C}$ circinal steel $\left(4 \mathrm{~cm}^{2}\right)$ onto the shaved skin for $10 \mathrm{sec}$ to cause a third degree burn. Immediately after the burn, all tree shrews were given an intraperitoneal injection (i.p.) of $0.5 \mathrm{~mL}$ of sterile physiological saline for fluid replacement to prevent overt shock and acetaminophen 
(0.25 $\mathrm{mg} / \mathrm{mL})$ was given as post burn analgesic in drinking water. Infection was induced by dropping $5 \times 10^{6}$ $\mathrm{CFU}$ of $S$. aureus on the surface of the wound. Bacterial counts were conducted 1,4 , and 7 days after infection $(n=6)$.

Twelve hours after inoculation, LEV and CPZ were administrated by subcutaneous injection (s.c.) twice a day for two days at doses of $8 \mathrm{mg} / \mathrm{kg}$ and $40 \mathrm{mg} / \mathrm{kg}$ body weight, respectively. Bacterial counts were conducted 4 days after infection $(n=7)$.

To characterize the histopathology of the skin infection model in tree shrew $(n=4)$, biopsy specimens were taken 4 days after inoculation. Immediately after the animals were sacrificed, skin samples were taken and immediately fixed in phosphate-buffered ( $\mathrm{pH}$ 7.4) formalin $(10 \%)$. The biopsy specimens were embedded in paraffin and stained with hematoxylin and eosin. At least four skin sections per tree shrew were analyzed.

\subsection{Graft infection model}

Tree shrews were anesthetized as described above, the hair on the back was shaved and the skin cleansed with $10 \% \mathrm{Na}_{2} \mathrm{~S}$ solution. One subcutaneous pocket was made on each side of the median line by a $1.5 \mathrm{~cm}$ incision. Aseptically, $1 \mathrm{~cm}^{2}$ sterile Dacron (BalMedic, china) was implanted into the pockets. Before implantation, the Dacron segments were impregnated with or without $4 \mathrm{mg} / \mathrm{mL} \mathrm{LEV} \mathrm{and} \mathrm{CPZ} \mathrm{in} 30 \mathrm{mg} / \mathrm{mL}$ chitosan gel for $30 \mathrm{~min}$, respectively. The pockets were closed by skin clips and a saline solution $(0.2 \mathrm{~mL})$ containing $2 \times 10^{6}$ CFU of $P$. aeruginosa 27853 was inoculated onto the Dacron graft surface. The animals were returned to individual cages and acetaminophen $(0.25 \mathrm{mg} / \mathrm{mL})$ was given as analgesic in drinking water. At days 1, 3 and 6 after infection, the animals were sacrificed to conduct bacterial counts $(n=7)$. For clinical examination, the wounds of tree shrew were photographed with a digital camera 3 days after infection.

\subsection{Bacterial counts}

The skin samples were cut and homogenized, and bacterial suspension was prepared for bacterial counts. Dacron grafts were placed in sterile tubes containing 1 $\mathrm{mL}$ of phosphate buffer saline and vibrated for $2 \mathrm{~min}$ to remove the adherent bacteria. Viable bacteria were obtained by culturing serial 10 -fold dilutions $(0.1 \mathrm{~mL})$ of the bacterial suspension on $\mathrm{LB}$ agar plates at $37{ }^{\circ} \mathrm{C}$ for $16 \mathrm{~h}$. The limit of detection for this method was approximately $100 \mathrm{CFU} / \mathrm{mL}$.

\subsection{Statistical analysis}

The MIC values were calculated as the geometric means of three separate experiments. The significance of differences in mean viable bacterial counts was assessed by the Kruskal-Wallis test. Significance was accepted when the $P<0.05$.

\section{Results}

\subsection{In vitro susceptibility of antibiotics}

Both LEV and CPZ are major antimicrobials used in treating bacterial infectious disease. We used the serial dilution method to determine the MIC of antibiotics. Under our experimental conditions, both antibiotics exhibited potent bactericidal activity to $P$. aeruginosa and $S$. aureus (Tab. 1). The MIC data for P. aeruginosa and $S$. aureus was in the susceptible range of each antibiotic. However, the MIC of LEV $(0.4 \mu \mathrm{g} / \mathrm{mL}$ and $0.8 \mu \mathrm{g} / \mathrm{mL}$, respectively) to $P$. aeruginosa and $S$. aureus was lower than CPZ (1.6 $\mu \mathrm{g} / \mathrm{mL}$ and $3 \mu \mathrm{g} / \mathrm{mL}$, respectively).

Tab. 1 in vitro susceptibility of antibiotics $(\mu \mathrm{g} / \mathrm{mL})$

\begin{tabular}{ccc}
\hline & $\begin{array}{c}\text { Staphylococcus } \\
\text { aureus } 25923\end{array}$ & $\begin{array}{c}\text { Pseudomonas } \\
\text { aeruginosa } 27853\end{array}$ \\
\hline $\mathrm{CPZ}$ & 3 & 1.6 \\
$\mathrm{LEV}$ & 0.8 & 0.4 \\
\hline
\end{tabular}

\subsection{Burned skin infection model}

Bacterial counts were used to evaluate the burnt skin infection model. Viable bacteria from the infected skin $\left(100 \mathrm{mg}\right.$ ) were $8 \log _{10} \mathrm{CFU} 12 \mathrm{~h}$ after application of $5 \times 10^{6}$ CFU of $S$. aureus (Fig. 1). There was no significant difference in the numbers of CFU per wound at $12 \mathrm{~h}$ versus 4 days of untreated group. The infection in tree shrew with $S$. aureus persisted 7 days without obvious change. No death occurred in any groups during in vivo study.

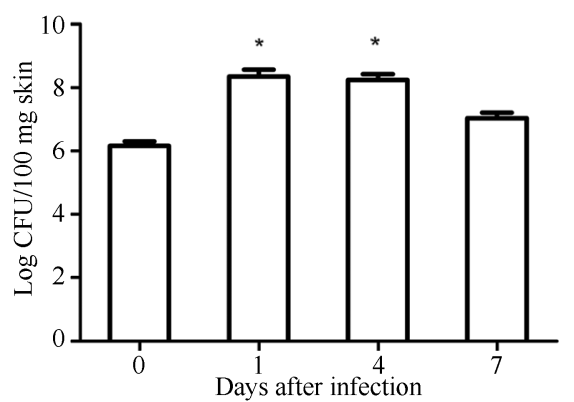

Fig. 1 Bacterial counts in the burnt skin infection model $5 \times 10^{6} \mathrm{CFU}$ of Staphylococcus aureus were inoculated on the surface of wound after a third degree burn was induced. Bacterial counts were conducted at 0 , 1,4 and $7 \mathrm{~d}$ after inoculation. ${ }^{*} P<0.05$ versus $3 \mathrm{~d}$ post inoculation. 


\subsection{Dacron graft infection model}

No death occurred in any groups in the graft infection model. Bacteria were detected in all tree shrews infected by $P$. aeruginosa at the end of experiment. Inoculation with $2 \times 10^{6} \mathrm{CFU} / \mathrm{graft}$ of $P$. aeruginosa led to severe infection in the tree shrews (Tab. 2). We observed $7.3 \log _{10} \mathrm{CFU} / \mathrm{mL}$ of $P$. aeruginosa $3 \mathrm{~d}$ after inoculation. Interestingly, there were no obvious infectious symptoms in Kun Ming mice after infection with this dose of $P$. aeruginosa (data not shown). Six days after inoculation, a large numbers of bacteria were observed in the Dacron grafts. In the negative control, however, no bacteria were detected in the Dacron graft without $P$. aeruginosa infection. In addition, obvious infectious symptoms were observed in the photograph of wounds obtained 3 days post inoculation (Fig. 2). Large amounts of pus were observed in the infection group, in contrast, only slight inflammation was observed in the group without infection.

Tab. 2 Bacterial counts in Dacron graft after inoculation of Pseudomonas aeruginosa

\begin{tabular}{cc}
\hline Group & $\begin{array}{c}\text { Mean bacterial counts } \\
\left(\log _{10} \mathrm{CFU} / \mathrm{mL}\right) \pm S D \text { (no. of grafts) }\end{array}$ \\
\hline Inoculum size & $5.996 \pm 0.5233$ \\
1 day post-infection & $7.021 \pm 0.2269^{\mathrm{a}}(7)$ \\
3 days post-infection & $7.329 \pm 0.2878^{\mathrm{b}}(7)$ \\
6 days post-infection & $7.859 \pm 0.2570^{\mathrm{c}}(6)$ \\
\hline
\end{tabular}

${ }^{\mathrm{a}} P>0.05$ versus inoculum size; ${ }^{\mathrm{b}} P<0.05$ versus inoculum size; ${ }^{\mathrm{c}} P<0.001$ versus inoculum size; ${ }^{\text {a }} P>0$. 05 versus 3 days post infection and 6 days post infection.

\subsection{Antibiotics are effective in tree shrew infection models} In the burnt skin infection model, LEV $(8 \mathrm{mg} / \mathrm{kg})$

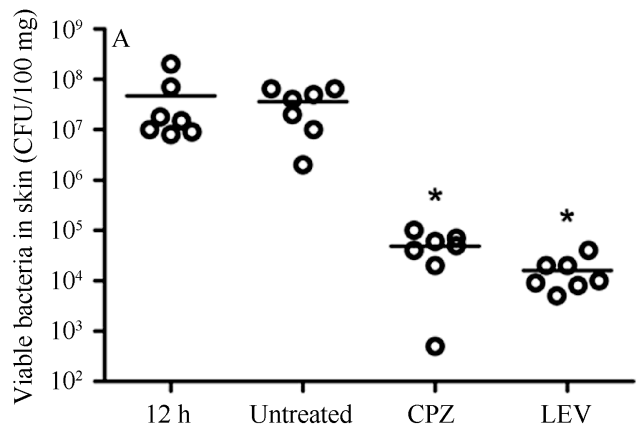

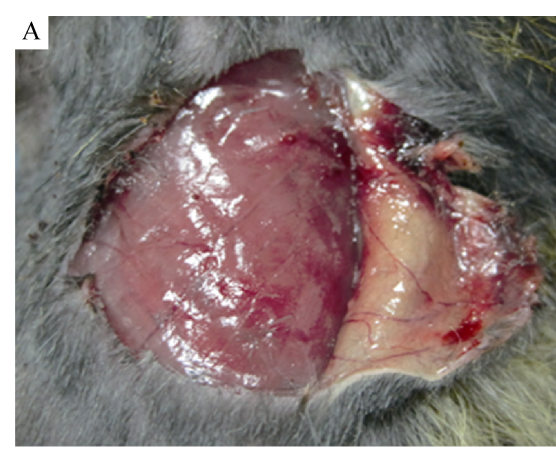

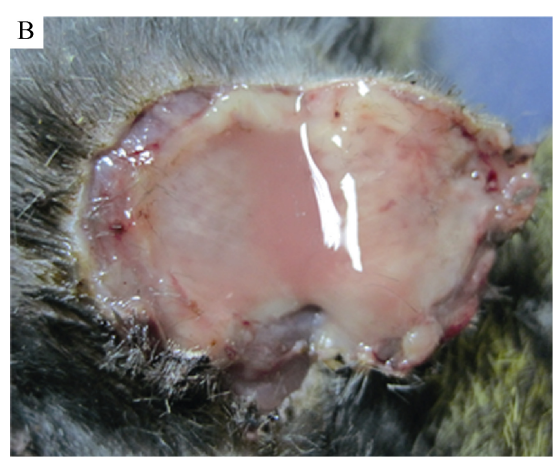

Fig. 2 Clinical examination of Dacron graft infection model induced by Pseudomonas aeruginosa

Representative images of non-infected (A) and infected skin (B) 3 days post inoculation.

and CPZ (40 mg/kg) were injected by s.c. Twelve hours after inoculation. LEV and CPZ reduced the bacterial counts to $4 \log _{10}$ and $5 \log _{10} \mathrm{CFU} / 100 \mathrm{mg}$ skin tissue, respectively. There was no significant difference between LEV and CPZ treatment. However, the differences between the antibiotic treatment group and untreated group were statistically significant $(P<0.05)$ (Fig. 3A).

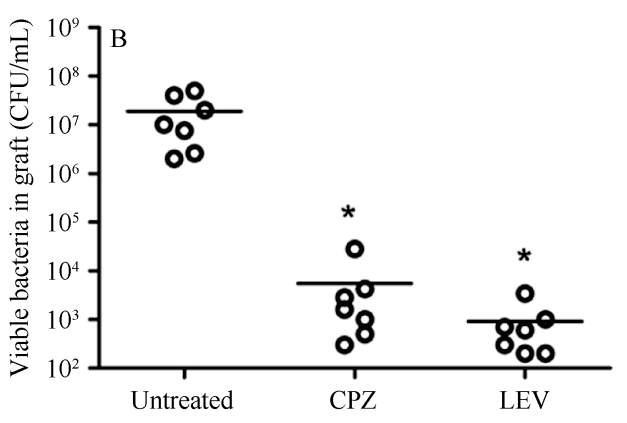

Fig. 3 Efficacy of antibiotics in tree shrew models

(A) Bacterial counts in burnt skin infection model; (B) Bacterial counts in Dacron graft infection model. $* P<0$. 05 versus untreated group.

In the Dacron graft infection model, Dacron segments were impregnated with or without $4 \mathrm{mg} / \mathrm{mL}$ LEV and CPZ in $30 \mathrm{mg} / \mathrm{mL}$ chitosan gel for $30 \mathrm{~min}$. Antimicrobials also prevented infection induced by $P$. aeruginosa. The number of bacteria in the graft were significantly reduced by $4 \log _{10} \mathrm{CFU} / \mathrm{mL}$ when comparing the antibiotic treatment group with the untreated group $(P<0.05)$ (Fig. 3B).

\subsection{Histological examination of burned skin infection model \\ To characterize the histopathological signs of} inflammatory response of the tree shrew after infection 
with $5 \times 10^{6} \mathrm{CFU}$ of $S$. aureus, skin samples were taken and stained with hematoxylin and eosin. In the burned tree shrew group without infection, the inflammatory response was slight compared with infected tree shrew (Fig. 4B). Obvious histopathological signs of inflammatory response were detected in tree shrews infected with $S$. aureus. Microscopic examination revealed a dense infiltration of leukocytes in subcutaneous tissues and deep dermis. Subcutaneous abscesses were also observed 4 days after infection (Fig. 4C). In contrast, no inflammatory responses were observed in normal skin of tree shrew (Fig. 4A).
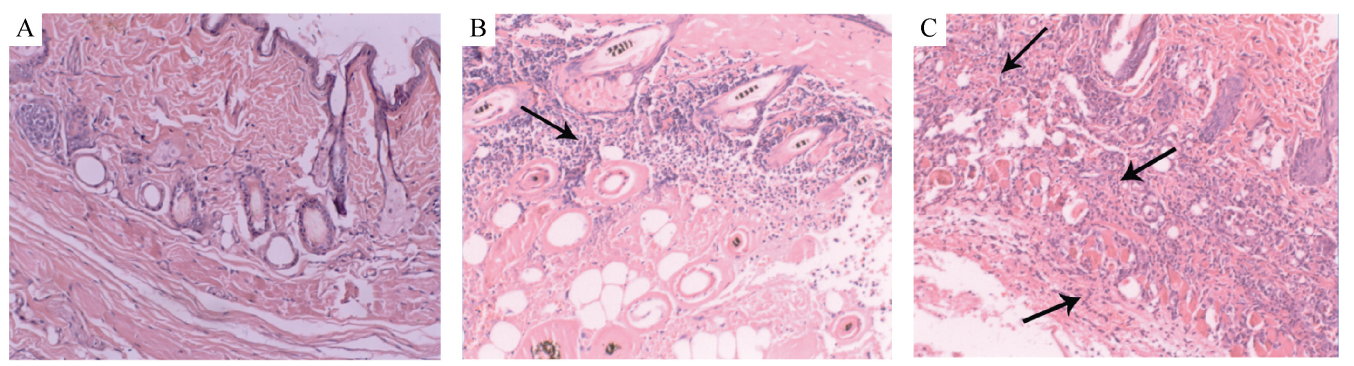

Fig. 4 Histological examination of burnt skin infection model

(A) normal skin; (B) burnt skin; (C) burnt skin with Pseudomonas aeruginosa infection. Arrows indicate the infiltration of leukocytes. Selected samples are shown at $\times 100$.

\section{Discussion}

The efficacy of antimicrobial drugs in animal models is very important during the development of new anti-infectious drugs (Craig, 1993). Some bacterial infection models have been developed in mice, rats, and rabbits, but none have been developed in small primatelike animals (Cao et al, 2003; Wada et al, 2008). Burnt skin infection and graft infection are severe diseases causing persistent infection, even sepsis (Rafla \& Tredget, 2011; Turgut et al, 2005). In the present study, we established two bacterial infection models induced by $P$. aeruginosa and $S$. aureus in tree shrew, which is considered as a novel primate-like experimental animal.

Both $P$. aeruginosa and $S$. aureus are major pathogens which cause severe topical and systemic infection in human. These two bacteria are opportunistic, usually causing infections in children and immune compromised patients (Giacometti et al, 2003; Tredget et al, 2004). It is surprising that these bacteria caused severe infection in tree shrew at a low infecting dose. In the burnt skin infection model, $8 \log _{10} \mathrm{CFU} / 100 \mathrm{mg}$ skin tissues were detected $12 \mathrm{~h}$ after inoculation with $5 \times 10^{6} \mathrm{CFU}$ of $S$. aureus per wound and the infection persisted for up to 7 days (Fig. 1). The integrity of skin can block infection induced by bacteria, so we establish this model by inoculating bacteria on the burnt skin. To insure the same burn degree in every tree shrew, the integrity of skin was determined by histological examination. The histopathological signs of inflammatory response were observed by histological examination four days after infection. Additionally, microscopic examination revealed a dense infiltration of leukocytes in subcutaneous tissues and deep dermis (Fig. 4). In the Dacron graft infection model, $7.3 \log _{10} \mathrm{CFU} / \mathrm{mL}$ of $P$. aeruginosa was observed 3 days after the inoculation with $2 \times 10^{6}$ CFU of $P$. aeruginosa per graft (Tab. 2). These two tree shrew infection models caused persistent infection after inoculation with $S$. aureus and $P$. aeruginosa, indicating we successfully established bacterial infection models in tree shrew. Interestingly, the dose of $P$. aeruginosa for the Dacron graft infection model in tree shrew did not induce a persistent infection in Kun Ming mice under our experimental conditions. To induce graft infection in Kun Ming mice with $P$. aeruginosa, more bacteria $\left(8 \log _{10} \mathrm{CFU}\right)$ were needed for Dacron graft infection when compared with tree shrew. The number of infection bacteria is critical for evaluating the therapeutic potential of new antimicrobials. Mice rapidly fight bacteria through their own immune ability, which may be the reason for the difficultly in establishing persistent infection in Kun Ming mice.

Furthermore, both topical treatment and graft precoated with antibiotics significantly reduced the bacterial number in the burnt skin infection model and in the Dacron graft infection model (Fig. 3A,B), suggesting the tree shrew bacterial infection models are able to evaluate the efficacy of novel antimicrobials in vivo. The results presented in this study show that tree shrew have several advantages as experimental animals for studying bacterial infection and evaluating the efficacy of new antibiotics, 
such as: (1) it is susceptible to $P$. aeruginosa and $S$. aureus; (2) it is easy to work with; and (3) antibiotics are effective in bacterial infection tree shrew models.

In conclusion, our findings demonstrate that tree shrew was susceptible to $P$. aeruginosa and $S$. aureus

\section{References:}

Cao J, Yang EB, Su JJ, Li Y, Chow P. 2003. The tree shrews: adjuncts and alternatives to primates as models for biomedical research $[\mathrm{J}]$. J Med Primatol, 32(3): 123-130.

Craig W. 1993. Relevance of animal models for clinical treatment[J]. Eur J Clin Microbiol Infect Dis, 12(Suppl 1): S55-S57.

Dale RMK, Schnell G, Wong JP. 2004. Therapeutic efficacy of "nubiotics" against burn wound infection by Pseudomonas aeruginosa[J]. Antimicrob Agents Chemother, 48(8): 2918-2923.

Druilhe P, Hagan P, Rook GAW. 2002. The importance of models of infection in the study of disease resistance[J]. Trends Microbiol, 10(10): S38-S46.

Fischbach MA, Walsh CT. 2009. Antibiotics for emerging pathogens[J]. Science, 325(5944): 1089-1093.

Giacometti A, Cirioni O, Gov Y, Ghiselli R, Del Prete MS, Mocchegiani F, Saba V, Orlando F, Scalise G, Balaban N, Dell'Acqua G. 2003. RNA III inhibiting peptide inhibits in vivo biofilm formation by drug-resistant Staphylococcus aureus[J]. Antimicrob Agents Chemother, 47(6): 1979-1983.

Givskov M, Hentzer M. 2003. Pharmacological inhibition of quorum sensing for the treatment of chronic bacterial infections[J]. J Clin Invest, 112(9): 1300-1307.

McCormick C, Caballero A, Tang AH, Balzli C, Song J, O'Callaghan R. 2008. Effectiveness of a new tobramycin $(0.3 \%)$ and dexamethasone $(0.05 \%)$ formulation in the treatment of experimental Pseudomonas keratitis[J]. Curr Med Res Opin, 24(6): 1569-1575.

McPhee JB, Hancock REW. 2005. Function and therapeutic potential of host defence peptides[J]. J Pept Sci, 11(11): 677-687.

Muller S, Stanyon R, O'Brien PC, Ferguson-Smith MA, Plesker R, Wienberg J. 1999. Defining the ancestral karyotype of all primates by multidirectional chromosome painting between tree shrews, lemurs and humans[J]. Chromosoma, 108(6): 393-400.

Niewiesk S, Prince G. 2002. Diversifying animal models: the use of hispid cotton rats (Sigmodon hispidus) in infectious diseases[J]. Lab Anim, 36(4): 357-372.

Oyston PCF, Fox MA, Richards SJ, Clark GC. 2009. Novel peptide and two bacterial infection models in tree shrew were established, indicating that tree shrew as a new experimental animal is suitable for establishing bacterial infection models and evaluating the efficacy of novel antimicrobial agents.

therapeutics for treatment of infections[J]. J Med Microbiol, 58(8): 977-987.

Rafla K, Tredget EE. 2011. Infection control in the burn unit[J]. Burns, 37(1): 5-15.

Retsema JA, Bergeron JM, Girard D, Milisen WB, Girard AE. 1993. Preferential concentration of azithromycin in an infected mouse thigh model[J]. J Antimicrob Chemother, 31(Suppl E): 5-16.

Russo TA, Beanan JM, Olson R, MacDonald U, Luke NR, Gill SR, Campagnari AA. 2008. Rat pneumonia and soft-tissue infection models for the study of Acinetobacter baumannii biology[J]. Infect Immun, 76(8): 3577-3586.

Tredget EE, Shankowsky HA, Rennie R, Burrell RE, Logsetty S. 2004. Pseudomonas infections in the thermally injured patient[J]. Burns, 30(1): 3-26.

Turgut H, Sacar S, Kaleli I, Sacar M, Goksin I, Toprak S, Asan A, Cevahir N, Tekin K, Baltalarli A. 2005. Systemic and local antibiotic prophylaxis in the prevention of Staphylococcus epidermidis graft infection[J]. BMC Infect Dis, 5: 91.

Wada T, Kida T, Inoue T, Tokushige H, Naka H, Sakaki H. 2008. Immunomodulatory effect of gatifloxacin on mouse peritoneal macrophages in vitro and in models of endotoxin-induced rat conjunctivitis and rabbit bacterial keratitis[J]. Ophthalmic Res, 40(2): 54-60.

Yang EB, Cao J, Su JJ, Li Y, Chow P. 2003. The tree shrews: adjuncts and alternatives to primates as models for biomedical research[J]. J Med Primatol, 32(3): 123-130.

Zasloff M. 2002. Antimicrobial peptides of multicellular organisms[J]. Nature, 415(6870): 389-395.

Zhang Y, Zhao H, Yu GY, Liu XD, Shen JH, Lee WH, Zhang Y. 2010. Structure-function relationship of king cobra cathelicidin[J]. Peptides, 31(8): 1488-1493.

Zhao XP, Tang ZY, Klumpp B, Wolff-Vorbeck G, Barth H, Levy S, von Weizsäcker F, Blum HE, Baumert TF. 2002. Primary hepatocytes of Tupaia belangeri as a potential model for hepatitis $\mathrm{C}$ virus infection[J]. J Clin Invest, 109(2): 221-232. 